\title{
微粒子を含む液の凝固における掃き出し・捕捉現象 Trapped and swept phenomenon of fine particle due to freezing
}

\author{
正 青木 和夫（長岡技科大） \\ 正赤堀 匡俊（長岡技科大） \\ $\bigcirc$ 鈴木 良明（長岡技科大院）
}

Kazuo AOKI ,Masatoshi AKAHORI and Yoshiaki SUZUKI, Nagaoka University of Technology 1603-1, Kamitomioka, Nagaoka 940-2188

Freezing phenomenon of solution including small particle has two special characteristics: (1) the particles are swept from freezing front, (2) the particles are trapped by the progress of freezing. In this paper, behavior of an isolated particle on the freezing front with freezing was investigated theoretically and experimentally. As the force acting on the particle, we considered electric double-layered force, van der Waals force, viscous drag and gravity forces, and proposed a theoretical model considered these forces. The predicted results were compared with the experimental results for electrolytic and non-electrolytic solutions. The critical freezing velocity (the maximum freezing velocity that the particle is swept on the frozen layer) depends on the particle diameter. Also, the critical freezing velocity in electrolytic solution rapidly decreases with the increase of electrolytic concentration on the freezing front.

Key Words: Freezing, Electric double layer, Fine particle, Electrolytic solution

\section{1. 緒言}

微粒子を含む液が凝固するとき、凝固界面上で粒子が掃き 出される場合と捕捉される場合がある。これらの現象は、複 合材料の高品質化と関連する粒子を含む金属の凝固、および 土壌の凍上現象などと関連して重要な問題である。

これまで，粒子を含む水の凝固に対する粒子の掃き出し・ 捕捉現象を取り扱い、分子間に働く van der Waals 力, 粘性抵 抗力, 重力および浮力を考慮したモデルによる理論解析およ び実験との比較検討を示した(1)。しかし, 電解質溶液中の粒 子の拡張した場合、電気二重層力の影響が重要となることが 実験的に示された(2)。

本研究では、van der Waals 力に加えて電気二重層力を考慮 した新しい解析モデルを提示するとともに、電解質水溶液と 非電解質水溶液を用いた実験結果との比較検討を行う。

\section{2. 疑固界面上での粒子挙動}

凝固面の進行にともない粒子が掃き出されるには, 凝固 面と粒子の隙間に常に溶液が存在し, 凝固にともないその隙 間に常に溶液が供給されなければならない。これを力学的に 捉えるならば, 凝固の進行により隙間が小さくなるとともに 粒子に㗢く上向きの力（斥力）が強くなることが必須の条件 となる。ここでは、粒子に㗢く相互作用力として van der Waals 力と電気二重層力を考慮に入れたモデルを示す。

\section{1 粒子に働く力}

\section{(1) 電気二重層力}

ガラス $\left(\mathrm{SiO}_{2}\right)$ 粒子のような酸化物の表面は、水溶液中で 水和を起こし、その表面には $\mathrm{OH}$ 基を有している。このよう な系では、分散水中の ph 值によって、正もしくは負へと帯 電する (3) (ph7 の水中でガラス粒子は負に帯電する)。そし て、粒子表面と逆の符号を持つ対イオンが带電表面に引き寄 せられ、表面近傍にイオン雲を形成する。これを電気二重層 と呼ぶ。この電気二重層が重なり合うと、重なった部分での イオン密度の過剩による浸透圧、あるいは Maxwell の張力が 变化し、結果として、電気二重層力が物体へと作用する。相 互作用がない状態での球状粒子と凝固層の表面電位をそれ ぞれ $\phi_{\mathrm{p}}$ および $\phi_{\mathrm{i}}$ とすると、無限凝固層上の単一粒子間に働 く電気二重層力 ${ }^{(1)} \mathrm{F}_{\mathrm{el}}$ は、次式で与えられる。

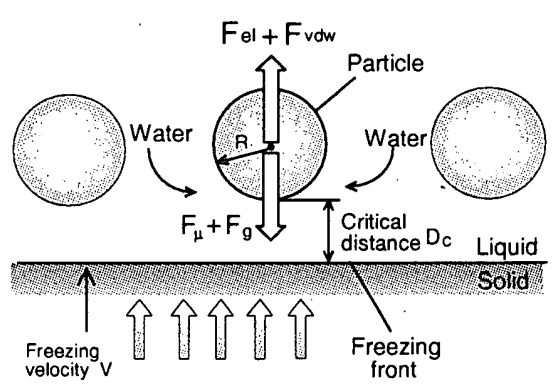

Fig I. Force acting on an isolated particle

$$
\begin{aligned}
F_{e l}(H)=\varepsilon_{0} \varepsilon_{r} \pi R & {\left[2 \phi_{p} \phi_{i} \frac{2 \kappa \exp (-\kappa D)}{1-\exp (-2 \kappa D)}\right.} \\
& \left.+\left(\phi_{p}^{2}+\phi_{i}^{2}\right) \frac{2 \kappa \exp (-2 \kappa D)}{1-\exp (-2 \kappa D)}\right]
\end{aligned}
$$

ここで、 $\mathrm{D}$ は粒子と界面との距離 $(\mathrm{m}) 、 \mathrm{R}$ は粒子半径 $(\mathrm{m}) 、 \varepsilon_{0}$ は真空の誘電率、 $\varepsilon_{\mathrm{r}}$ は液の比誘電率を表す。また、 $\kappa$ の逆数

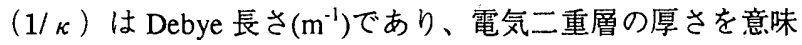
し、以下の式で与えられる。

$$
\frac{1}{\kappa}=\left(\frac{\varepsilon_{0} \varepsilon_{r} k T}{2 n z^{2} e^{2}}\right)^{\frac{1}{2}}
$$

ここで、 $\mathrm{k}$ は Boltzmann 定数 $(\mathrm{J} / \mathrm{K}), \mathrm{n}$ :バルクのイオン個数濃 度、 $\mathrm{z}$ はイオン価数、e は電気素量を表す。これより、Debye 長さは電解質濃度の増加にともない減少する。

(2) van der Waals 力

無限凝固層上の単一粒子間に㗢く van der Waalsr 力 $F_{v d w}$ は, 次式で与えられる(5)。

$$
F_{v d w}=-\frac{A R}{6 D^{2}}
$$

ここで, A は Hamaker 定数を表す。Hamaker 定数は様々な形 状の分子間相互作用を示す定数で，ここでは，媒質中の相互 作用に関するLifshitz 理論 (5)を適用し，次式により与えた。 


$$
\begin{aligned}
& A_{\text {Total }}=A_{\nu=0}+A_{\nu>0} \\
& \approx \frac{3}{4} k T\left(\frac{\varepsilon_{p}-\varepsilon_{w}}{\varepsilon_{p}+\varepsilon_{w}}\right)\left(\frac{\varepsilon_{i}-\varepsilon_{w}}{\varepsilon_{i}+\varepsilon_{w}}\right) \\
& +\frac{3 h \nu_{e}}{8 \sqrt{2}} \frac{\left(n_{p}^{2}-n_{w}^{2}\right)\left(n_{i}^{2}-n_{w}^{2}\right)}{\left(n_{p}^{2}+n_{w}^{2}\right)^{\frac{1}{2}}\left(n_{i}^{2}+n_{w}^{2}\right)^{\frac{1}{2}}\left\{\left(n_{p}^{2}+n_{w}^{2}\right)^{\frac{1}{2}}+\left(n_{i}^{2}+n_{w}^{2}\right)^{\frac{1}{2}}\right\}}
\end{aligned}
$$

ここで、hはPlanck定数 $(\mathrm{Js})$, \&は静的誘電率 $(\mathrm{F} / \mathrm{m}), \mathrm{n}$ は可視領 域における屈折率， $v_{\mathrm{e}}$ はUV領域における主電子吸収振動数 (Hz)を表す。また，添え字wは水，iは水，pは粒子を意味す る。この系では, Hamaker定数Aは負となり球状粒子と凝固 界面の間に㗢くvan der Waals力は斥力となる。

(3) 粘性抵抗力

凝固界面の進行に伴い，粒子と凝固界面の間に液体が流入 するとき、粒子は下向きの粘性抵抗力 $F_{\mu}$ を受ける。粒子と凝 固界面の間に流入する液体の速度を二次元 Poiseuille 流れと し、流入量と粒子の凝固界面への投影面積に対応する凝固量 がバランスすると仮定すると，粘性抵抗力 $F_{\mu}$ は以下の式で整 理される。

$$
F_{\mu}=6 \mu R V \pi \frac{R}{D}
$$

ここで、 $\mu$ は液体の粘性係数 $(\mathrm{Pa} \cdot \mathrm{s}) 、 \mathrm{~V}$ は凝固界面の進行速 度 $(\mathrm{m} / \mathrm{s})$ である。

\section{(4) 重力および浮力}

粒子に作用する重力および浮力 Fg は次式で与えられる。

$$
F_{g}=\frac{3}{4} \pi R^{3}\left(\rho_{p}-\rho_{w}\right) g
$$

ここで、 $\mathrm{g}$ は重力加速度 $\left(\mathrm{m} / \mathrm{s}^{2}\right) 、 \rho$ は密度 $\left(\mathrm{kg} / \mathrm{m}^{3}\right)$ である。

\section{2 臨界准固速度}

図1のモデルに示すように、粒子に㗢く上記のすべての力 の釣り合いより次式が成り立つ。

$$
F_{e l}+F_{v d w}=F_{\mu}+F_{g}
$$

いま、凝固層と粒子の間隙に液が供給されなくなる限界の 臨界距離 Dc を仮定すると、力の釣り合い式(7)上り対応する 臨界凝固速度 Vc が次式で与えられる。

$$
V_{c}=\frac{D_{c}}{6 \pi \mu R^{2}}\left[F_{e l}+F_{v d w}-\frac{4}{3} \pi R^{3}\left(\rho_{p}-\rho_{w}\right) g\right]
$$

すなわち、この臨界凝固速度以上の凝固速度では粒子は凝固 層に捕捉され、以下では凝固層から粒子は掃き出されること を意味する。

\section{3.計算結果と実験結果の比較}

解析結果と前報で得られた実験結果の比較検討を行う。 (a) 水の凝固

はじめに、媒質が非電解質である水の凝固に対する粒子の 捕捉・掃き出しについて検討する。図 2 はそれぞれの粒子径 に対し，凝固速度を変化させた実験から得られた掃き出し

（X）および捕捉（○）の実験結果を示す。凝固速度の上昇 にともない掃き出しから捕捉に遷移し，その臨界凝固速度は 粒子径が大きくなるとともに低下する。図中に示す線は、式 (8)を用い、臨界距離 $\mathrm{D}_{\mathrm{c}}$ を水分子直径 $\left(\mathrm{a}_{0}\right)$ の倍数と仮定して得 られた臨界凝固速度の理論值を表す。計算結果は傾向的には 実験結果と良い対応を示しており，計算結果と実験結果との マッチングから，臨界距離 $\mathrm{D}_{\mathrm{c}}$ を水分子直径の 12 倍程度

$\left(\mathrm{Dc}=12 \mathrm{a}_{0}\right)$ と考えると実験結果を見積もることができる。 なお、水の電解質濃度は不純物の存在を考慮し $10^{-5}(\mathrm{~mol} / \mathrm{l})$ と した。

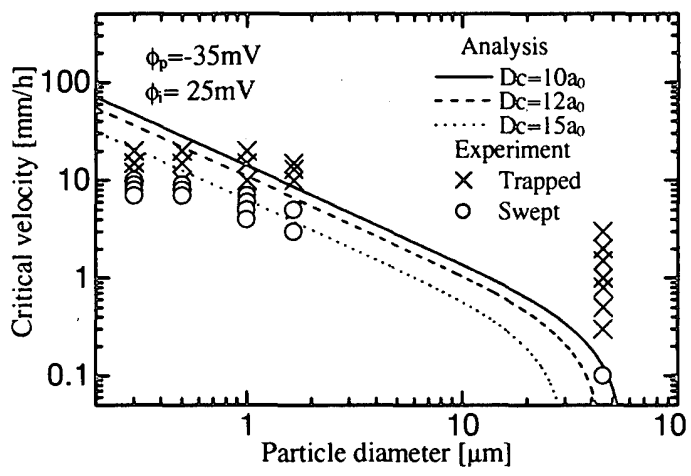

Fig2.Relationship between particle diameter and Vc

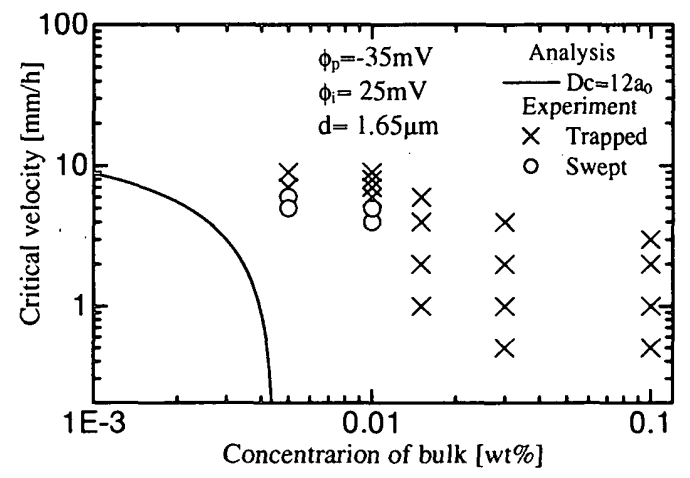

Fig3. Relationship between concentration of bulk and Vc

(b) 電解質水溶液中での粒子挙動

次に、媒質が電解質である $\mathrm{NaCl}$ 水溶液の凝固に対する粒 子の捕捉・掃き出しについて検討する。図 3 はそれぞれの電 解質濃度に対し、凝固速度を変化させた実験から得られた掃 き出し $(\times)$ および捕捉 $(O)$ の実験結果を示す。ここで、 ガラス粒子の直径は $1.65 \mu \mathrm{m}$ である。電解質水溶液では、電 解質濃度の増加に伴い掃き出しから捕捉へ遷移する臨界凝 固速度は急激に低下する。特に $\mathrm{NaCl}$ 水溶液濃度が $0.015 \mathrm{wt} \%$ 程度の希薄水溶液でも粒子の掃き出し現象は観察されない。 これは電解質濃度の増加にともない電気二重層厚さが減少 し、斥力である電気二重層力が低下するためと考えられる。 図中に示す線は、(2)および(8)式を用い臨界距離 $\mathrm{Dc}=12 \mathrm{a}_{0}$ と仮 定して、電解質濃度に対する臨界凝固速度を理論的に求めた 結果である。濃度の増加にともない臨界凝固速度が急激に低 下する傾向は理論的に表現できるが、実験結果は高濃度側に シフトする結果となる。

\section{4. 結言}

ガラス粒子を含む液の凝固現象を取り扱い，凝固時に生じ る粒子の掃き出し・捕捉現象を、van der Waals 力および電気 二重層力を考慮した新しいモデルを提示するとともに、電解 質水溶液と非電解質水溶液を用いた実験結果との比較検討 を行った。

\section{参考文献}

(1) 赤堀·他 3 名:日本機械学会北陸信越支部第 37 期講演論 文集 p.353-354, (2000)

(2) 赤堀・他 2 名:第 38 回日本伝熱シンポジウム講演論文集 p821-822, (2001)

（3）北原·古澤：最新コロイド科学 p50-51,(1990)

(4) S.USUI : J.Colloid Interface Sci., 44, p107-113, (1973)

(5) J. N. Israelachvili：表面間力と分子間力, 朝倉書店, (1996) 